\title{
GLOBAL EXPERIENCE OF SOCIAL ENTREPRENEURSHIP DEVELOPMENT
}

\author{
Valentyn Halunko', Andriy Ivanyshchuk ${ }^{2}$ \\ Research Institute of Public Law, Ukraine
}

Tereziia Popovych ${ }^{3}$

Uzhhorod National University, Ukraine

\begin{abstract}
The purpose of the article - to reveal features of the implementation of social entrepreneurship in the world. Methodology. The theoretical and methodological framework of scientific developments consists of the research of scientists of modern times who work on the solution to development issues of social entrepreneurship in countries of the world, research data of consulting institutes, own research results. In order to provide validity of research results, the following methods are used: generalization - in the critical analysis of the content of works of scientists on solving the problems of the development of social entrepreneurship; information-logical analysis - when studying data of international consulting institutes and associations; comparison - when comparing directions of the state support for the development of social entrepreneurship in different countries of the world; cause and effect relationship - for obtaining final conclusions. Results. This article reveals optimal conditions for developing social entrepreneurship in countries of the world. A portrait of a successful entrepreneur of the world is formed. The state of social entrepreneurship and the directions of its development in advanced countries of Europe, America, and Asia are analysed. Possibilities of adaptation of the global experience in the social entrepreneurship development for Ukraine are determined. Practical importance. Results of this research can be useful for the Ministry of Social Policy of Ukraine, the Ministry of Economic Development and Trade of Ukraine. Value/originality - there are clarified conditions and strategic measures on the development of social entrepreneurship in Ukraine. Further research should be aimed at the improvement of stimulating mechanisms for the social entrepreneurship development as a global tool for solving problems of the socio-economic development of countries of the world.
\end{abstract}

Key words: Social enterprise, social entrepreneurship, conditions of social entrepreneurship development, state support, Europe, America, Asia.

JEL Classification: 138, H44, L31

\section{Introduction}

The world experience persuasively testifies that even the growth of socially necessary costs, social responsibility in the field of entrepreneurship, and improvement of the functioning of the "third sector" of economies of many countries of the world are not able to solve the whole complex of existing socio-economic problems. This lays emphasis on a low efficiency of interaction of public sector and business structures, activities of organizations of the "third sector" towards overcoming unemployment, social inequality, numerous wars, ethnic rivalries, gender discrimination, poverty, etc. And, then, is the main reason for deepening research related to studying the role of social entrepreneurship as one of the forms of business organization, as well as stimulating mechanisms for its development in the world economic practice of entrepreneurship.

\section{Literature review}

Social entrepreneurship as a scientifically meaningful problem became widespread in the early $90 \mathrm{~s}$ of the XX century; it was interpreted as an innovative approach, by which individuals can solve the serious social problems that their community faces (Drayton, 2011). The concept of the social entrepreneurship development and the promotion of the social economy

\footnotetext{
Corresponding author:

${ }^{1}$ Research Institute of Public Law.

E-mail: halunkov@i.ua

${ }^{2}$ Research Institute of Public Law.

E-mail: Ivanyshchuk@i.ua

${ }^{3}$ Department of Theory and History of State and Law, Uzhhorod National University.

E-mail:ptp@urk.net
} 
is now a part of the EU's policy to overcome the social isolation of people in a fragile situation. As a result, the search for ways of achieving social goals within the framework of sustainable and inclusive growth, reflecting the experience of Bulgaria, is of a significant interest (Terziev, Nichev and Arabska, 2017). Generalization of American and European experience in social entrepreneurship, approaches of Russian scholars based on empirical research data (Hoogendoorn, Pennings and Thurik, 2010; Poltavskaya, 2015) allows asserting that social entrepreneurship as a branch of scientific research is at the stage of birth. And thus, there are virtually no effective mechanisms for its development stimulation. At the same time, development of theoretical provisions of social entrepreneurship, as confirmed by current studies, should be based on results of analysis, which covers the contribution of value generation, value comparing, and resource exchange efficiency and social entrepreneurship should be seen as an integration structure that promotes a clearer understanding of the process of creating social value (Hlady-Rispal and Servantie, 2018). In the context of the direction of these studies, the authors propose a variety of examples of solving social problems, in particular, the creation of municipal Economic Justice Incubators, the purpose of which is to solve the problems of employment of former prisoners (Baskaran, 2018). The importance of distributing non-profit organizations in the field of healthcare is also emphasized; in particular, the experience of India in this direction is interesting. In order to improve the sustainability of charity hospitals, it is proposed to focus attention on ensuring long-term financial well-being, disseminating and integrating the best practices of this type of social enterprises by expanding learning opportunities and sharing knowledge (Chowdhury, 2015). For certain countries of the world suffering from socio-economic conflicts as a result of hostilities, ethnic rivalries, social entrepreneurship is considered as a mechanism for their solution on the set of positive effects from the activities of social enterprises and taking into account scenarios of the possible course of events in society, given the existing trends in the world (Kryvovyazyuk and Haranchevskaya, 2017). Along with that, one should note the relationship of social entrepreneurship with the concept of sustainable development, which is achieved through the social reorganization and inclusive entrepreneurship (Saxena, 2011). This can serve an opportunity for further adaptation of separate regulatory tools, which positively influence the sustainability of the socio-economic ecosystem in the nearest region of the enterprise operation in relation to the stimulation of development of social entrepreneurship in whole. It is also necessary to study features of state regulation of socio-economic responsibility of business (Batchenko and Dielini, 2017), which can be a positive experience for Ukraine.

\section{Conditions for social entrepreneurship development in the world and successful social entrepreneur's portrait}

According to data from the research of famous American foundation (Thomson Reuters Foundation, 2016), top 15 countries with the best conditions for the development of social entrepreneurship include today the USA, Canada, Great Britain, Singapore, Israel, Chile, South Korea, Hong Kong, Malaysia, France, Switzerland, Germany, Italy, Columbia, and India. These countries have formed the best governmental support for social entrepreneurship, conditions for attracting qualified personnel, receiving respectable wages, attracting investments, understanding by the society of the need for social changes, provision of the growth of this sector of the economy.

This convincingly shows that social entrepreneurship has become widespread in a large part of the world countries due to the principles of activities aimed at solving the existing social problems by means of introducing innovative entrepreneurial methods of work and providing the effect of a scale that reaches the international boundaries. Along with that, each team of social entrepreneurs is oriented to leaders who, due to their exclusive initiative and volunteering provide the accessibility of objectives to be achieved.

If we reduce all leaders of the rating of successful social entrepreneurs of the world to uniform parameters (Forbes Gallery, 2012), their portrait will be as follows: they are mostly men (66.7\%) aged 18-28, less often - women (33.3\%) aged 20-29; absolute majority of them - representatives of the USA (70.0\%), also there are representatives of Asia (12.9\%), Europe (6.5\%), Africa (6.5\%), and other continents $(4.1 \%)$; all of them are founders or cofounders of social entrepreneurial structures, and sometimes combine it with their activities' management as general directors; among the selected spheres of social assistance, the priority belongs to medicine $(20.0 \%)$, education and learning (20.0\%), dissemination of information technology (20.0\%), energy preservation (10.0\%), issues of ecology and environmental protection (6.67\%), solving food supply problems $(6.67 \%)$, issue of infrastructural development $(6.66 \%)$, and other services $(10.0 \%)$; by scale of development of social assistance, activities of entrepreneurs are directed to the solution of problems: in the world in whole $(23.3 \%)$, in countries of Africa (33.3\%), in countries of Asia (13.4\%), in countries of America (30.0\%).

Research results showed that the most active social entrepreneurs direct the main attention to satisfy secondary and tertiary needs of people - in preserving health, education, as well as in solving environmental problems. 


\section{The state of social entrepreneurship and the directions of its state support in the advanced countries of Europe}

A number of countries of the world - Great Britain, Germany - are among the countries with the best conditions for developing social entrepreneurship.

According to research data of SEUK (Temple and Gregory, 2017), in Great Britain, there are 67-70 thousand social enterprises, employing about 1 million workers, generating about 24 billion pounds sterling of revenue from activities, according to various estimates. A significant share of social enterprises operates up to 5 years (49\%). About 34\% of such enterprises carry out activities at the local level. More than $75 \%$ of trade income accounts for $74 \%$ of social enterprises, the largest share of which accounts for the state sector of the economy (20\%). About $18 \%$ of income comes from international activities. The share of social enterprises, which produces innovations, in Great Britain is 50\%, while among small and medium-sized businesses only $33 \%$. It should be noted that two-thirds of social enterprises support people from disadvantaged groups, and $44 \%$ employ them. The average salary of the head of a social enterprise is 36115 pounds sterling. About 51\% of social enterprises are looking for funding of fewer than 100000 pounds sterling. The most common form of financing activities - grants ( $82 \%$ of social enterprises applied for grants).

Such an activity is achieved due to the legislative consolidation of social entrepreneurship, local authorities' support, and proper regulation of the development of social entrepreneurship. Among the most effective methods and forms of state support for this sector should be distinguished: preferential taxation, state financing, support for enterprises engaged in the development of the local community by giving a priority to participation in tenders, promotion of the development of social entrepreneurs' vocational education, creation of an investment fund of financial support for the development of social entrepreneurship, creation of a department of social entrepreneurship issues at the Department of Trade and Industry, interaction of public authorities with non-state, public organizations, oriented to social entrepreneurship, associations and unions of entrepreneurs (Social Enterprise UK).

As the results of the research program "Social Entrepreneurship as a Force for more Inclusive and Innovative Societies" (SEFORÏS, 2016) show, in Germany, there are now about 100 thousand social enterprises employing about 2.5 million workers. About 29\% of social enterprises operate for less than 5 years. Germany is defined by the prevalence of social enterprises' cooperation with the national government (21\%) along with the cooperation with local and regional governments. The share of German social enterprises producing innovation is $88 \%$, which is the third indicator in the world after Sweden and China. Activities of social enterprises of this country focus on the development of the community, employment, and training (25\%), education and research (22\%), and healthcare $(15 \%)$. The main sources of financing of German social enterprises are levies and sales in the market or governments (43\%), grants (29\%), and donations (10.5\%).

Directions of state support for social enterprises of Germany include: exemption from corporate income tax, inclusion of social enterprises as separate categories of target groups in state support schemes, financing of such enterprises by the national development bank and EU structural funds, promotion of volunteering, social enterprises' support at the local and regional levels, legislative consolidation of development of social entrepreneurship.

\section{The state of social entrepreneurship and the directions of its state support in the advanced countries of America}

The USA is the best country where business leaders strive to solve social problems. According to research data (Social Enterprise Alliance, 2018), there are about 140 thousand social enterprises registered in the country that receive over 500 billion dollars of income and provided jobs to more than 10 million citizens, whose wage fund is at least $8.3 \%$ of the country's payroll budget. Along with that, up to $40 \%$ of these enterprises have fewer than five employees and only $8 \%$ - more than 100 employees; $45 \%$ of enterprises have income less than 250 thousand dollars; $22 \%$ - more than 2 million dollars; $35 \%$ of social enterprises - non-profit organizations; $20 \%$ - affect the economic development of the USA; $16 \%$ - focus on the workforce development; less than $10 \%$ - focus on the international level.

State support for the development of social entrepreneurship in the USA is one of the best in the world and ranks 6th in the ranking of the best countries for the development of social entrepreneurship (Thomson Reuters Foundation, 2016) and is realized in the following directions: stimulating social innovation, creating favourable conditions for support, promoting the dissemination and development of successful social initiatives, disseminating information on effective solutions to social entrepreneurship. One should also note a significant role of the Social Enterprise Alliance in the support for social enterprises of the USA.

Canada occupies the second place in the world for the creation of conditions for the development of social entrepreneurship, including the first by the possibility of access to capital, the ability of social entrepreneurs to make a living due to work, as well as the pace of development of social entrepreneurship (Thomson Reuters Foundation, 2016). The number of social 
enterprises in the country increases annually and is close to their number in the USA. Thus, only Ontario has registered 10 thousand social enterprises that have formed investment capital of 2.5 billion USD. Social enterprises of Canada (Elson, P., Hall, P. and Wamucii P., 2016) mostly operate at the local level (58\%), much less at the national (13\%) and international level (10\%). The main financial sources of their activity are grants $(77 \%$ of social enterprises), banking credits (8\%), finances of credit associations (7\%), government structures (2\%), financing of private persons.

The state significantly promotes the development of social entrepreneurship by means of support for social initiatives, promotion of volunteering, social entrepreneurs benefit from Social Venture ConneXion the first platform named MaRS and TMX group that unites social enterprises with funds and investors.

\section{The state of social entrepreneurship and the directions of its state support in the advanced countries of Asia}

Among the countries of Asia that create the best conditions for the development of social entrepreneurship, there are Singapore, South Korea, Hong Kong, Malaysia. Along with that, we consider appropriate to distinguish those providing the best state support towards the solution of social problems South Korea and Singapore that fairly took the first and the second places correspondingly in the field of state regulation of social processes (Thomson Reuters Foundation, 2016).

Development of social entrepreneurship in Singapore (Watanabe and Tanaka, 2016) is considerably promoted by a lower corporate tax $(17 \%)$ compared to other Asian economies - Japan (40\%), China (25\%), and South Korea (24\%). In 2015, the National Council of Social Service (NCSS), Ministry of Social and Family Development (MSFD), Tote Board, and SEA established a new centre named "raiSE" for supporting the development of social enterprises by means of creating a centralized support window. It provides services to new social entrepreneurs on issues of financial support (in the form of grants and investments for covering different business stages, including startups), advisory services (on issues of cooperation with large corporations), education services (providing educational programmes), provision of offices. About three out of five social enterprises in Singapore participate in raiSE and took advantage of these additional opportunities.

South Korea, unlike most of the countries with favourable development conditions for social entrepreneurship, has a much smaller number of social enterprises. According to research results (Cagney, 2018), there are 1814 entities, however, all of them are certified by the Ministry of Labour and Employment
Affairs and KoSEA, which allows receiving significant preferences from the state and, in particular, funds for the reimbursement of labour costs. Social enterprises employ about 30 thousand people; the share of their contribution to the country's GDP structure is $3 \%$. In their activities, enterprises are oriented to solving problems of energy saving, education, international expansion in order to reduce unemployment and develop agriculture (Hwang, Jang, Park, Kim, 2017).

State support for social entrepreneurship in South Korea has a dual nature: on the one hand -it considerably strengthens the sector where social enterprises operate, on the other - weakens business development as a whole. Along with that, the main directions of the state support for the development of social entrepreneurship are the financing of the support for social initiatives, tax preferences, institutional provisions, and support for the international markets' entry.

\section{Possibilities of adaptation of the world experience in development and regulation of social entrepreneurship for Ukraine}

Analysis of the global experience in development and regulation of social entrepreneurship in the advanced countries of Europe, America, and Asia points out that its adaptation is possible and useful. However, it will become possible taking into account the following conditions: firstly, it is necessary to legalize social entrepreneurship as in advanced countries of the world; secondly, national doctrine for the development of social entrepreneurship is required that will enable determining the tactics and strategy of actions to solve social goals; thirdly, it is needed to generate in society an understanding of the importance of social entrepreneurship as a global tool that can stimulate business development as a whole.

As the first-priority steps that can improve adaptation of the global experience in the development of social entrepreneurship for Ukraine, it is necessary: to introduce specialties "Social Entrepreneurship" and "Regulation of Social Entrepreneurship Development" in the training of specialists of economic and legal directions in higher educational institutions of the country; for advanced social enterprises - to become fullfledged participants of the Social Enterprise Alliance; to create a Centre for supporting the development of social enterprises; to introduce a mechanism for cooperation of the state, business, and community in the area of development of social entrepreneurship.

\section{Conclusions}

Analysis of scientific papers of scientists of modern times showed that the role of social entrepreneurship in the development of the global economy is constantly increasing, requiring a deeper study of ways to achieve 
social goals in the advanced countries and, at the same time, features of state support for the development of social entrepreneurship.

Research results outline that social entrepreneurship development conditions can be considered the best if there are provided: its proper governmental support, optimal conditions for attracting skilled personnel, respectable wages, investment attraction for the development of social entrepreneurship, understanding in the society of the need for social changes, ensuring the growth of this sector of the economy.

Analysis of the world experience in the development of social entrepreneurship points out that in the advanced countries of Europe, high activity of this sector is achieved due to legislative consolidation of its role in the economy of countries, support on the part of local authorities, proper regulation of development of social entrepreneurship, grant activities; in the advanced countries of America - by means of stimulating social innovations on the part of the state, creating favourable conditions for supporting this sector's development, dissemination of information data on viable solutions of the social entrepreneurship field; in the advanced countries of Asia - due to financing of the support for social initiatives, tax discrimination, institutional provision, support for the international markets' entry.

For Ukraine, such an experience is useful, first of fall, from a perspective of the need of assigning a legal status to social enterprises, provision of the understanding in the society of the need for these changes, elaboration of ways to stimulate the development of social entrepreneurship and create a platform for solving a number of social problems - unemployment, low wages.

Further research should be aimed at the improvement of stimulating mechanisms for the social entrepreneurship development as a global tool for solving problems of the socio-economic development of countries of the world.

\section{References:}

Baskaran, Pr. (2018). Respect the Hustle: Necessity Entrepreneurship, Returning Citizens, and Social Enterprise Strategies (March 20, 2018), 78 Md. L. Rev. (2019 Forthcoming). Retrieved from: https://ssrn.com/ abstract $=3144791$ (accessed March 20, 2018).

Batchenko, L. and Dielini, M. (2017). International aspects of state regulation of socio-economic responsibility of entrepreneurship: experience for Ukraine. Baltic Journal of Economic Studies. Vol. 3. No 5. P. 13-18.

Cagney, P. (2018). Global Best Practices for CSO, NGO, and Other Nonprofit Boards: Lessons From Around the World, Hoboken, New Jersey: John Wiley \& Sons, Inc., 304 p.

Chowdhury, I. (2015). Resilience and Social Enterprise: The Case of Aravind Eye Care System. In J. Ryan (Ed.), Summit on Resilience II: The Next Storm. New York: Pace University, p. 19-26. Retrieved from: https://ssrn.com/ abstract $=3076674$.

Deok Soon Hwang, Wonbong Jang, Joon-Shik Park, Shinyang Kim (2017). Social enterprise in South Korea, Social Enterprise Journal, Vol. 13 Issue: 4, pp. 362-375. Retrieved from: https://doi.org/10.1108/SEJ-09-2017-0047.

Drayton B. (2011). Collaborative entrepreneurship: how social entrepreneurs can tip the world by working in global teams. Innovations 6.2, p. 35-38.

Forbes Gallery (2012): 30 Under 30: Social Entrepreneurs. Forbes. Retrieved from: https://www.forbes.com/ special-report/2012/30-under-30/30-under-30_social.html.

Hlady-Rispal, M. and Servantie, V. (2018). Deconstructing the Way in Which Value is Created in the Context of Social Entrepreneurship. International Journal of Management Reviews, Vol. 20, Issue 1, pp. 62-80. Retrieved from: https://ssrn.com/abstract=3104236or http://dx.doi.org/10.1111/ijmr.12113 (accessed January 2018).

Hoogendoorn, Br., Pennings, E. and Thurik, R. (2010). What Do We Know About Social Entrepreneurship: An Analysis of Empirical Research. ERIM Report Series Reference No. ERS-2009-044-ORG. Retrieved from: https://ssrn.com/abstract=1462018 (accessed January 2010).

Kryvovyazyuk, I. and Haranchevskaya I. (2017). Sotsialne pidpryiemnytstvo ta yoho rol u vyrishenni sotsialnoekonomichnykh konfliktiv (Social Entrepreneurship and its role in solving social-economic conflicts). Protsesne upravlinnia ta korporatyvna sotsialna vidpovidalnist pidpryiemnytskykh struktur (Process control and corporate Social responsibility of Entrepreneurship structures). Materialy mizhn. nauk.-prakt. internet-konf. (International science-practical internet conference materials). Lutsk: Tower-Print, pp. 163-165 (accessed December 2017).

OECD/EU (2017). Boosting Social Enterprise Development: Good Practice Compendium, OECD Publishing, Paris. 248 p. Retrieved from: http://dx.doi.org/10.1787/9789264268500-en.

Elson, P., Hall, P. and Wamucii P. (2016). Canadian National Social Enterprise. Sector Survey Report. Retrieved from: https://ccednet-rcdec.ca/sites/ccednet-rcdec.ca/files/final-national-report-may-16-2016.pdf.

Poltavskaya, M. (2015). Sotsialnoe predprinimatelstvo kak ideia i kak protsess: vzgliad nekommercheskikh organizatsii (Social Entrepreneurship as an Idea and as a Process: A View of Non-Profit Organizations). Vestnik Volgogradskogo gosudarstvennogo universiteta. Seriia 7: Filosofiia. Sotsiologiia i sotsialnye tekhnologii № 3 (29). pp. 136-150. Retrieved from: https://ssrn.com/abstract=3086289 (accessed December 11, 2015).

Saxena, M. (2011). New Dimensions of Sustainability Through Social Entrepreneurship. Retrieved from: 
https://ssrn.com/abstract=1780848 (accessed March 8, 2011).

SEFORÏS (2016). A first analysis and profiling of social enterprises in Germany prepared by the SEFORÏS research consortium. Country report Germany. Berlin: SEFORÏS. 35 p. Retrieved from: https://www.hertie-school.org/fileadmin/2_Research/2_Research_directory/Research_projects/SEFORIS/ Country-Report-DE_EN-FINAL.pdf.

Social Enterprise Alliance (2018). Retrieved from: http://socialenterprisecensus.org/.

Temple, N. and Gregory, D. (2017). The Future of Business: State of Social Enterprise Survey 2017. London: SEUK. 48 p. Retrieved from: https://www.socialenterprise.org.uk/Handlers/Download.ashx?IDMF=a1051b2c21a4-461a-896c-aca6701cc441.

Terziev, V., Nichev, N. and Arabska, E. (2017). Analiz na razvitieto na sotsialnoto predpriemachestvo v Balgariya (Analysis of the Development of Social Entrepreneurship in Bulgaria).Jubilee Scientific Conference with International Participation of Theme: «Modern Trends $»$. Retrieved from: https://ssrn.com/abstract=3149034 (accessed May 2017).

Thomson Reuters Foundation (2016). The best countries to be a Social Entrepreneur 2016. Retrieved from: http://poll2016.trust.org/.

Watanabe, T. and Tanaka Y. (2016). Study of social entrepreneurship and innovation ecosystems in South East and East Asian countries: country analysis: Republic of Singapore / The Japan Research Institute. Retrieved from: https://publications.iadb.org/bitstream/handle/11319/8063/Study-of-Social-Entrepreneurship-and-InnovationEcosystems-in-South-East-and-East-Asian-Countries-Country-Analysis-Republic-of-Singapore.pdf?sequence=1. 